\title{
Sexual Selection and Canine Dimorphism in New World Monkeys
}

\author{
R.F. KAY, J.M. PLAVCAN, K.E. GLANDER, AND P.C. WRIGHT \\ Department of Biological Anthropology and Anatomy, Duke University, \\ Durham, North Carolina 27710
}

\author{
KEY WORDS Platyrrhini, Primates, Dental anatomy, Sexual \\ dimorphism
}

\begin{abstract}
Social and ecological factors are important in shaping sexual dimorphism in Anthropoidea, but there is also a tendency for body-size dimorphism and canine dimorphism to increase with increased body size (Rensch's rule) (Rensch: Evolution Above the Species Level. London: Methuen, 1959.) Most ecologists interpret Rensch's rule to be a consequence of social and ecological selective factors that covary with body size, but recent claims have been advanced that dimorphism is principally a consequence of selection for increased body size alone. Here we assess the effects of body size, body-size dimorphism, and social structure on canine dimorphism among platyrrhine monkeys.

Platyrrhine species examined are classified into four behavioral groups reflecting the intensity of intermale competition for access to females or to limiting resources. As canine dimorphism increases, so does the level of intermale competition. Those species with monogamous and polyandrous social structures have the lowest canine dimorphism, while those with dominance rank hierarchies of males have the most canine dimorphism. Species with fission-fusion social structures and transitory intermale breeding-season competition fall between these extremes.

Among platyrrhines there is a significant positive correlation between body size and canine dimorphism However, within levels of competition, no significant correlation was found between the two. Also, with increased body size, body-size dimorphism tends to increase, and this correlation holds in some cases within competition levels.

In an analysis of covariance, once the level of intermale competition is controlled for, neither molar size nor molar-size dimorphism accounts for a significant part of the variance in canine dimorphism. A similar analysis using body weight as a measure of size and dimorphism yields a less clear-cut picture: body weight contributes significantly to the model when the effects of the other factors are controlled. Finally, in a model using head and body length as a measure of size and dimorphism, all factors and the interactions between them are significant. We conclude that intermale competition among platyrrhine species is the most important factor explaining variations in canine dimorphism. The significant effects of size and size dimorphism in some models may be evidence that natural (as opposed to sexual) selection also plays a role in the evolution of increased canine dimorphism.
\end{abstract}

It is generally recognized that there are many "causes" for sexual dimorphism in primates and other mammals. Four sorts of mechanisms have been proposed to explain dimorphism: phyletic inertia, correlated response, natural selection, and sexual selec- tion. Explanations that invoke phyletic inertia (Cheverud et al., 1985a,b) depict di-

Received September 21, 1987; accepted May 17, 1988.

Address reprint requests to Dr. R.F. Kay, Department of Biological Anthropology and Anatomy, Box 3170, Duke University Medical Center, Durham, NC 27710. 
morphism in a species as an adaptation of its ancestors that is not explicable as part of that species' current adaptations. Sexual dimorphism has also been viewed as a nonselected "correlated response" to overall selection favoring either 1) an increase in body size or 2) an increased body-size dimorphism (Leutenegger and Cheverud, 1982, 1985): in this view, selection favoring increased size produces a correlated increase in dimorphism when there is unbalanced phenotypic variability between the sexes or a difference between male and female heritabilities for the dimorphic trait; by the same token body-size dimorphism might "drag" canine dimorphism along with it. The third class of explanations for dimorphism involves natural (as distinct from sexual) selection, e.g., differential resource utilization by the sexes, and different roles of the sexes for defense against predation (Richard, 1974; Clutton-Brock et al., 1977; Leutenegger and Kelly, 1977; Harvey et al., 1978; CluttonBrock and Harvey, 1978; Smith, 1980; Anderson, 1986).

Finally, ever since Darwin, sexual selection has been invoked to explain sexual dimorphism. In this model, dimorphism is maintained or enhanced because females prefer to mate with males having certain morphological attributes or because dimorphic traits confer an advantage in intermale competition (Darwin, 1871; Trivers, 1972; Brown, 1975; Harcourt et al., 1976).

There are also many different ways that sexual dimorphism is expressed. There may be differences in body size, color patterns, body shape, or canine size, to name a few of these. The degree of dimorphism in these various anatomical features is probably under different selective pressure and this probably explains, for example, why dimorphism in body weight and canine size do not precisely covary in primates. In this paper we use a comparative approach to consider canine sexual dimorphism in relation to the above possible causes. We particularly are interested in the degree to which variation in intermale competition is sufficient to explain dimorphism in platyrrhine canines and the degree to which canine dimorphism and body-size dimorphism respond similarly with changes in social structure and/or size.

\section{MATERIALS AND METHODS Social structure}

To avoid the possibility of bias in the outcome of this study, Glander and Wright, working independently, and without prior knowledge of the morphological findings of Kay and Plavcan, gathered data from the literature and from personal observations to produce the classification of social structure presented here. In this analysis, four levels of social structure are recognized in platyrrhine primates. At each ascending level there is an increase in the degree of intermale competition. Table 1 summarizes the taxa used in this study according to social structure and the level of competition. In level 1, once breeding units are established, there is little or no competition among males for breeding access to mates. There are two such social structures among platyrrhines. In polyandry, seen in most or all Callitrichinae, two or more males copulate with a single female during one breeding season and cooperate to raise the offspring (e.g., Terborgh and Goldizen, 1985). In monogamy, which occurs in many other platyrrhines, including Aotus and Callicebus, one adult pair breeds exclusively over several mating seasons (e.g., Wright, 1986).

In levels 2-4, significant breeding competition occurs. Platyrrhines at these levels are characterized by multimale/multifemale troops. In level 2 there is limited intermale competition for breeding access to females. Such a breeding pattern occurs in fissionfusion social groups. For example, in Ateles promiscuous mating may occur during the breeding season within nonpermanent subgroups drawn from a larger, more stable community (Klein and Klein, 1975; Symington, personal communication). Alternatively, estrous females may form consort pairs away from the group. Level 2 competition also is found in Brachyteles, which lives in multimale/multifemale groups. Male Brachyteles show little aggression in competing for sexual access to receptive females (Aguire, 1971; Milton, 1985; Strier, 1986). In the level 3 breeding pattern, exemplified by Cebus capucinus and Saimiri, competition among males occurs primarily during the mating season (Robinson and Janzen, 1987). At other times of the year, there is less intermale competition. Finally, intermale competition is most extreme in level 4 species. Often, as in Alouatta, an established hierarchy among males is maintained throughout the year (Rudran, 1979; Glander, 1980; Clarke, 1983; Crockett and Eisenberg, 1987). This hierarchy may determine not only which males have access to mates during the breeding season but also may confer an advantage on 
TABLE 1. Summary of levels of intermale competition for the species used in this study, as defined in the text, and the behavioral data on which the classification was based

\begin{tabular}{|c|c|c|c|}
\hline Taxon & Social structure & $\begin{array}{c}\text { Competition } \\
\text { level }\end{array}$ & References \\
\hline \multicolumn{4}{|l|}{ Callithrix } \\
\hline jacchus jacchus & Monogamy/polyandry ${ }^{a}$ & 1 & Alonso (1984) \\
\hline jacchus penicillata & Monogamy/polyandry ${ }^{2}$ & 1 & Hershkovitz (1977) \\
\hline \multicolumn{4}{|l|}{ Cebuella } \\
\hline pygmaea pygmaea & Monogamy/polyandry ${ }^{a}$ & 1 & $\begin{array}{l}\text { Hernandez-Camacho } \\
\text { \& Cooper (1986) }\end{array}$ \\
\hline \multicolumn{4}{|l|}{ Saguinus } \\
\hline $\begin{array}{l}\text { fuscicollis nigrifrons } \\
\text { midas niger }\end{array}$ & Polyandry ${ }^{\mathrm{b}}$ & 1 & Goldizen \& Terborgh (1986) \\
\hline $\begin{array}{l}\text { midas niger } \\
\text { oedipus geoffroyi }\end{array}$ & $\begin{array}{l}\text { ?Polyandry } \\
\text { Polyandry }\end{array}$ & $\begin{array}{r}? 1 \\
1\end{array}$ & $\begin{array}{l}\text { None } \\
\text { Dawson (1977): }\end{array}$ \\
\hline oedipus geoftroyl & & & $\begin{array}{l}\text { Dawson (1977); } \\
\text { Neyman (1977) }\end{array}$ \\
\hline \multicolumn{4}{|l|}{ Leontopithecus } \\
\hline \multicolumn{4}{|l|}{ Alouatta } \\
\hline belzebul & Unknown & & None \\
\hline caraya & Dominance rank competition $^{d}$ & 4 & Thorington et al. (1984) \\
\hline fusca & Dominance rank competition & 4 & Da Silva (1981) \\
\hline palliata & Dominance rank competition & 4 & Milton (1978) \\
\hline pigra & Dominance rank competition & 4 & $\begin{array}{l}\text { Coelho et al. (1976); } \\
\text { Watts et al. (1986) }\end{array}$ \\
\hline seniculus insulanus & Dominance rank competition & 4 & Neville (1972) \\
\hline \multicolumn{4}{|l|}{ Ateles } \\
\hline fusciceps fusciceps & Fission/fusion ${ }^{\mathrm{e}}$ & 2 & Klein \& Klein (1975) \\
\hline fusciceps robustus & ? Fission/fusion & ?2 & None \\
\hline geoffroyi vellerosus & Fission/fusion & 2 & Fedigan \& Baxter (1984) \\
\hline \multicolumn{4}{|l|}{ Brachyteles } \\
\hline arachnoides & Multimale/multifemale & 2 & Aguire (1971); \\
\hline & low competition or Fis/Fus & & $\begin{array}{l}\text { Milton (1985); } \\
\text { Strier (1986) }\end{array}$ \\
\hline \multicolumn{4}{|l|}{ Lagothrix } \\
\hline flaricauda & $\begin{array}{l}\text { Multimale/multifemale } \\
\text { low competition }\end{array}$ & 2 & Leo Luna (1980) \\
\hline $\begin{array}{l}\text { lagotricha lagotricha } \\
\text { Aotus }\end{array}$ & Unknown & $?$ & None \\
\hline \multicolumn{4}{|l|}{ Aotus } \\
\hline $\begin{array}{l}\text { trivirgatus griseimembra } \\
\text { trivirgatus lemurinus }\end{array}$ & Monogamy & 1 & Wright (1978) \\
\hline $\begin{array}{l}\text { trivirgatus lemurinus } \\
\text { trivirgatus trivirgatus }\end{array}$ & ?Monogamy & $? 1$ & None \\
\hline \multicolumn{4}{|l|}{ Callicebus } \\
\hline moloch discolor & Monogamy & 1 & Kinzey et al. (1977) \\
\hline torquatus lugens & Monogamy & 1 & Defler (1983) \\
\hline \multicolumn{4}{|l|}{ Cebus } \\
\hline $\begin{array}{l}\text { apella libinosus } \\
\text { capucinus capucinus }\end{array}$ & Dominance rank competition & 4 & Janson (1984) \\
\hline $\begin{array}{l}\text { capucinus capucinus } \\
\text { Saimiri }\end{array}$ & Mating season competition & 3 & Freese \& Oppenheimer (1981) \\
\hline \multicolumn{4}{|c|}{ ent } \\
\hline sciureus macrodon & Mating season competition & $\begin{array}{l}3 \\
3\end{array}$ & $\begin{array}{l}\text { Hershkovitz (1977) } \\
\text { Klein \& Klein (1975) }\end{array}$ \\
\hline oerstedii oerstedii & Mating season competition $^{\mathrm{h}}$ & 3 & $\begin{array}{l}\text { Baldwin \& Baldwin (1981); } \\
\text { Boinski (1987) }\end{array}$ \\
\hline \multicolumn{4}{|r|}{ DOInSk1 (1901) } \\
\hline \multirow{3}{*}{$\begin{array}{l}\text { Chiropotes } \\
\text { satanas chiropotes } \\
\text { Pithecia } \\
\text { pithecia }\end{array}$} & & & \\
\hline & Monogamy & 1 & Ayres (1981) \\
\hline & $\begin{array}{l}\text { Multimale/multifemale low } \\
\text { competition }\end{array}$ & 2 & $\begin{array}{l}\text { Buchanon et al. (1981); } \\
\text { Oliveira et al. (1985) }\end{array}$ \\
\hline
\end{tabular}

${ }^{1}$ Notes: a, lack of agreement as to the type of social organization; b, reference population is $S$. $f$. weddelli from Peru; c, reference population is from Bolivia; $d$, reference population is from Argentina; e, reference population is $A$. belzebul from Colombia; f, at Manu study site in Peru, extreme breeding season competition occurs involving the death of some males (C. Janzen and C. Mitchell, personal communication); g, reference population is from Columbia; $h$, breeding season described as being at a comparatively low level; $\ddot{i}$, this species found in multimale/multifemale groups, but reported to be monogamous within these groups. 
TABLE 2. Sample sizes of males and females, canine dimorphism, Canine Dimorphism Index (CDI), ln female $M^{1}$ area, and $M^{1}$ area dimorphism for each of the species studies ${ }^{1}$

\begin{tabular}{|c|c|c|c|c|c|c|c|c|}
\hline \multirow[b]{2}{*}{ Taxon } & \multirow[b]{2}{*}{$\mathrm{M} / \mathrm{F}$} & \multicolumn{4}{|c|}{ Canine dimorphism } & \multirow[b]{2}{*}{ CDI } & \multirow{2}{*}{$\begin{array}{c}\ln \\
\text { female } \\
\mathrm{M}^{1} \text { area }\end{array}$} & \multirow[b]{2}{*}{$\begin{array}{c}\mathrm{M}^{1} \text { area } \\
\text { dimorphism }\end{array}$} \\
\hline & & $\begin{array}{c}\mathrm{C}_{1} \\
\max \end{array}$ & $\begin{array}{c}\mathrm{C}_{1} \\
\text { min }\end{array}$ & $\begin{array}{c}\mathrm{C}^{1} \\
\max \end{array}$ & $\begin{array}{c}\mathrm{C}^{1} \\
\min \end{array}$ & & & \\
\hline Callithrix jacchus jacchus & $5 / 3$ & 1.05 & .99 & 1.04 & 1.06 & 1.035 & 1.980 & .991 \\
\hline Callithrix jacchus penicillata & $3 / 5$ & 1.03 & 1.02 & .99 & .97 & 1.003 & 1.972 & 1.054 \\
\hline Cebuella pygmaea pygmaea & $14 / 23$ & .99 & 1.01 & .99 & 1.01 & 1.000 & 1.455 & .988 \\
\hline Saguinus fuscicollis nigrifrons & $19 / 15$ & .97 & .97 & 1.00 & .98 & .980 & 2.055 & .924 \\
\hline Saguinus midas niger & $31 / 25$ & .98 & 1.01 & 1.03 & .99 & 1.002 & 2.110 & .986 \\
\hline Saguinus oedipus geoffroyi & $21 / 21$ & 1.02 & 1.01 & 1.04 & 1.00 & 1.017 & 2.277 & .993 \\
\hline Leontopithecus rosalia rosalia & $4 / 6$ & 1.12 & 1.02 & 1.05 & 1.01 & 1.050 & 2.596 & 1.045 \\
\hline Alouatta belzebul & $10 / 10$ & 1.46 & 1.35 & 1.37 & 1.52 & 1.426 & 3.910 & 1.175 \\
\hline Alouatta caraya & $10 / 10$ & 1.36 & 1.31 & 1.30 & 1.38 & 1.338 & 3.815 & 1.201 \\
\hline A louatta fusca & $8 / 10$ & 1.48 & 1.36 & 1.37 & 1.41 & 1.405 & 3.916 & 1.133 \\
\hline Alouatta palliata aequatorialis & $14 / 13$ & 1.32 & 1.29 & 1.26 & 1.26 & 1.283 & 3.945 & 1.114 \\
\hline Alouatta pigra & $7 / 10$ & 1.24 & 1.25 & 1.28 & 1.25 & 1.255 & 3.964 & 1.057 \\
\hline Alouatta seniculus insulanus & $12 / 10$ & 1.36 & 1.25 & 1.40 & 1.32 & 1.331 & 3.868 & 1.235 \\
\hline Alouatta seniculus seniculus & $11 / 10$ & 1.35 & 1.20 & 1.39 & 1.30 & 1.309 & 3.939 & 1.176 \\
\hline Ateles fusciceps fusciceps & $1 / 2$ & 1.17 & 1.11 & 1.15 & 1.11 & 1.135 & 3.430 & 1.137 \\
\hline Ateles fusciceps robustus & $1 / 3$ & 1.17 & 1.05 & 1.04 & 1.21 & 1.118 & 3.332 & .943 \\
\hline Ateles geoffroyi vellerosus & $22 / 19$ & 1.19 & 1.14 & 1.00 & 1.12 & 1.113 & 3.391 & 1.008 \\
\hline Ateles paniscus chameh & $10 / 15$ & 1.15 & 1.07 & 1.07 & 1.11 & 1.100 & 3.379 & 1.000 \\
\hline Brachyteles arachnoides & $4 / 4$ & 1.24 & 1.21 & 1.08 & 1.10 & 1.158 & 4.039 & 1.184 \\
\hline Lagothrix flavicauda & $2 / 1$ & 1.08 & 1.08 & 1.00 & 1.14 & 1.075 & 3.754 & .810 \\
\hline Lagothrix lagotricha poepigii & $27 / 26$ & 1.24 & 1.15 & 1.21 & 1.29 & 1.223 & 3.463 & .970 \\
\hline Aotus trivirgatus griseimembra & $2 / 4$ & 1.04 & .97 & .97 & .93 & .978 & 2.532 & .908 \\
\hline Aotus trivirgatus lemurinus & $13 / 13$ & 1.07 & 1.02 & .99 & 1.02 & 1.025 & 2.505 & .999 \\
\hline Aotus trivirgatus trivirgatus & $10 / 19$ & 1.05 & 1.04 & 1.01 & 1.07 & 1.043 & 2.528 & 1.028 \\
\hline Callicebus moloch discolor & $12 / 7$ & .98 & 1.03 & .98 & .98 & .993 & 2.700 & 1.000 \\
\hline Callicebus torquatus lugens & $10 / 10$ & 1.01 & .99 & 1.03 & 1.01 & 1.010 & 2.733 & .983 \\
\hline Cebus apella libinosus & $18 / 21$ & 1.29 & 1.23 & 1.17 & 1.18 & 1.218 & 3.267 & 1.036 \\
\hline Cebus capucinus capucinus & $28 / 25$ & 1.18 & 1.16 & 1.08 & 1.22 & 1.161 & 3.196 & 1.049 \\
\hline Saimiri oerstedii oerstedii & $26 / 19$ & 1.42 & 1.13 & 1.12 & 1.33 & 1.251 & 2.205 & .974 \\
\hline Saimiri sciureus macrodon & $24 / 11$ & 1.22 & 1.10 & 1.15 & 1.21 & 1.170 & 2.314 & 1.015 \\
\hline Saimiri sciureus boliviensis & $6 / 3$ & 1.28 & 1.13 & 1.03 & 1.23 & 1.169 & 2.346 & 1.022 \\
\hline Cacajao calvus & $11 / 3$ & 1.22 & 1.15 & 1.24 & 1.15 & 1.190 & 3.074 & 1.020 \\
\hline Chiropotes satanas chiropotes & $15 / 16$ & 1.06 & 1.05 & 1.10 & 1.06 & 1.067 & 2.683 & 1.030 \\
\hline Pithecia pithecia & $14 / 11$ & 1.16 & 1.17 & 1.20 & 1.17 & 1.175 & 2.777 & .988 \\
\hline
\end{tabular}

${ }^{1}$ Each dimorphism value is the ratio of mean male dimension to the mean female dimension (dimensions were not $1 n$ transformed prior to calculating sexual dimorphism). Dimensions are as follows: $\mathrm{C}_{1}$ max: maximum diameter of the lower canine at its base; $C_{1}$ min: minimum diameter at right angles to $C_{1} \max ; C^{1}$ max: maximum diameter of the upper canine at its base; $\mathrm{C}^{1}$ min: maximum diameter at right angles to $\mathrm{C}^{1}$ max. Calculation of $\mathrm{CDI}$ is explained in the text.

dominant males for access to resources throughout the year. If so, then canine dimorphism in species with level 4 social structure could be selected in response to both sexual and natural selection.

\section{Morphological data}

The morphological data used in this study document the amount of sexual dimorphism in the canines of platyrrhines. Estimates also were made of body size based on the natural logarithms of 1) the area of the upper first molars of females $\left(\mathrm{M}^{1}\right.$ area was calculated as the product of $\mathrm{M}^{1}$ mesiodistal length times buccolingual breadth), 2) the head and body length of adult females, and 3) the body weight of adult females. Estimates of bodysize dimorphism were based on 1) the ratio of male $M^{1}$ area to female $M^{1}$ area, 2) the ratio of male head and body length to female head and body length, and 3) the ratio of male body weight to female body weight. Tables 2 and 3 summarize these data.

All dental measurements were made on original specimens by using a Wild M5 stereomicroscope fitted with a calibrated reticle. Measurement consistency was plus or minus $3.2 \%$ on average; 34 species or subspecies of platyrrhines, representing 15 of 16 extant genera, were sampled (see Table 2 for sample sizes). Each dental sample comes from a small area of the overall range of the species to hold interdeme variation to a minimum. 
TABLE 3. Female head and body lengths and body weights (natural logs), head and body length dimorphism, and body-weight dimorphism ${ }^{1}$

\begin{tabular}{|c|c|c|c|c|}
\hline \multirow[b]{2}{*}{ Species } & \multicolumn{2}{|c|}{ ln female } & \multicolumn{2}{|c|}{ Dimorphism } \\
\hline & $\begin{array}{l}\text { H\&B } \\
\text { length }\end{array}$ & $\begin{array}{c}\text { Body } \\
\text { weight }\end{array}$ & $\begin{array}{c}\text { H\&B } \\
\text { length }\end{array}$ & $\begin{array}{c}\text { Body } \\
\text { weight }\end{array}$ \\
\hline Callithrix jacchus & 5.366 & 5.943 & .981 & .950 \\
\hline Cebuella pygmaea & 4.970 & 4.890 & .924 & .872 \\
\hline Saguinus fuscicollis & 5.394 & - & .968 & - \\
\hline Saguinus midas & 5.529 & - & .976 & - \\
\hline Saguinus oedipus & 5.606 & 6.286 & 1.022 & 1.039 \\
\hline Leontopithecus rosalia & - & 6.174 & - & 1.152 \\
\hline Alouatta belzebul & 6.230 & - & 1.161 & - \\
\hline Alouatta caraya & - & 8.496 & - & 1.557 \\
\hline Alouatta fusca & 6.148 & - & 1.194 & - \\
\hline Alouatia palliata & 6.254 & 8.695 & 1.079 & 1.240 \\
\hline Alouatta seniculus & 6.267 & 8.770 & 1.102 & 1.252 \\
\hline Ateles geoffroyi & - & 8.973 & - & .937 \\
\hline Ateles paniscus & 6.292 & - & 1.009 & - \\
\hline Brachyteles arachnoides & 6.351 & 9.159 & 1.038 & $\ldots$ \\
\hline Lagothrix flavicauda & 6.254 & - & 1.000 & - \\
\hline Lagothrix lagotricha & 6.194 & 8.678 & 1.073 & 1.163 \\
\hline Aotus trivirgatus & 5.832 & 6.802 & 1.015 & 1.024 \\
\hline Callicebus moloch & 5.884 & 6.242 & 1.009 & 1.325 \\
\hline Callicebus torquatus & 6.064 & - & .972 & - \\
\hline Cebus apella & 5.966 & 7.693 & 1.138 & 1.207 \\
\hline Cebus capucinus & 5.999 & 7.888 & 1.149 & 1.430 \\
\hline Saimiri oerstedii & 5.652 & 6.603 & 1.098 & 1.212 \\
\hline Saimiri sciureus & 5.743 & 6.430 & 1.019 & 1.266 \\
\hline Cacajao calvus & 6.319 & 8.175 & .991 & - \\
\hline Chiropotes satanas & 5.984 & 7.972 & 1.113 & - \\
\hline Pithecia pithecia & 5.852 & 6.965 & 1.184 & 1.223 \\
\hline
\end{tabular}

${ }^{\mathrm{t}} \mathrm{Head}$ and body length (H\&B) data from Napier (1976). Body-weight data from Hershkovitz (1977); Kay (1973); Leutenegger and Cheverud (1982); van Roosmalen et al. (1981); and Fontaine (1981).

As measures of canine dimorphism, we used the greatest canine diameter and the diameter at right angles to it in the occlusal plane on both upper and lower canines of males and females. In Table 2, four estimates of canine dimorphism are presented: 1 ) mean male lower canine occlusal length divided by mean female lower canine occlusal length, 2) mean male lower canine occlusal breadth divided by mean female lower canine occlusal breadth, 3) mean male upper canine occlusal length divided by mean female upper canine occlusal length, and 4) mean male upper canine occlusal breadth divided by mean female upper canine occlusal breadth.

The four initial measures of canine $\mathrm{di}$ morphism described above were found to be highly intercorrelated (Table 4). To derive a single measure of dimorphism, a principalcomponents analysis was undertaken on the correlation matrix of the four male/female measurement ratios of each species. The first principal component (PCI) of this analysis accounts for $92 \%$ of the total variance, and the factor loadings for the four initial variables are very similar (Table 5). A species having male/female canine size of 1.00 for each of the four initial measures of dimorphism will have a PCI value of -2.00 . Therefore we use $\mathrm{PCI} /-2.00$ as a canine dimorphism index (CDI). This index is 1.00 if there is no canine dimorphism and theoretically would be 2.00 if male canines were twice as large as those of females. CDIs are presented in Table 2.

To avoid the possibility that the data points are not statistically or biologically independent (e.g., Clutton-Brock and Harvey, 1978; Ridley, 1983), in tests for correlation between dimorphism and body size (i.e., molar area, head and body length, and body weight) we considered two subsets of the data: 1) where any species was represented by more than one subspecies or population, we selected the largest sample to represent that species for the analysis; 2) in a second analysis, we selected the largest sample of one species for each genus. 
TABLE 4. Product-moment correlations among the four canine dimorphism estimates (measurements defined in Table 2; all correlations significantly different from zero at the 0.001 level)

\begin{tabular}{lccccc} 
& \multicolumn{2}{c}{ Lower canine } & & \multicolumn{2}{c}{ Upper canine } \\
\cline { 2 - 5 } & Max & Min & & Max & Min \\
\hline Lower canine & & & & \\
$\quad$ Max & 1.00 & - & -- & - \\
$\quad$ Min & 0.90 & 1.00 & -- & - \\
Upper canine & & & & \\
$\quad$ Max & 0.82 & 0.86 & 1.00 & - \\
Min & 0.94 & 0.88 & 0.84 & 1.00 \\
\hline
\end{tabular}

TABLE 5. Eigenvalues for the first principal component of the analysis of dimorphism

\begin{tabular}{ll} 
Lower canine maximum & -0.506 \\
Lower canine minimum & -0.503 \\
Upper canine maximum & -0.485 \\
Upper canine minimum & -0.506 \\
\hline
\end{tabular}

\section{RESULTS \\ Canine dimorphism and body size}

The effects of body size on canine dimorphism are considerable but appear to be more a consequence of the fact that large platyrrhine species tend to have more breeding competition than small species. To assess these effects we calculated the correlations between CDI and ln female molar area, ln female head and body length, and $\ln$ female body weight. Irrespective of which measure of body size is chosen, canine dimorphism increases as body size increases in platyrrhines. The product-moment correlation coefficients between CDI and molar area, head and body length, and body weight for species are $0.76,0.61$, and 0.67 , respectively (Table 6 ;) when the sample is composed of just one species per genus the correlations between the variables are $0.62,0.57$, and 0.64 (Table 8). All these correlations are significantly different from zero at the 0.01 level or better.

TABLE 6. Correlations between CDI and three measures of body size in platyrrhine species: 1) ln female $M^{1}$ area, 2) ln female head and body length, and 3) ln female body weight ${ }^{1}$

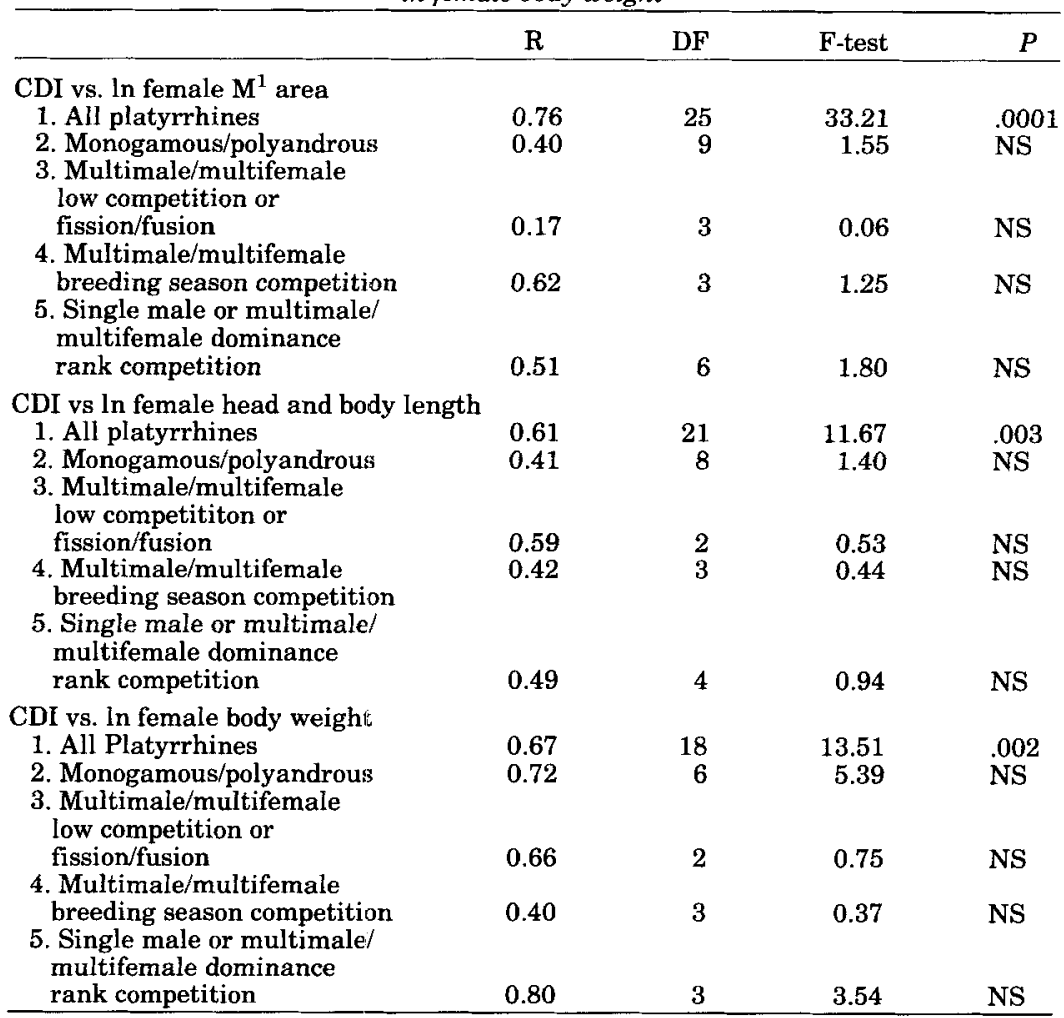

${ }^{1}$ Just one subspecies is selected to represent each species. For canine and molar dimorphism, samples are used only when each species is presented by three of more specimens of each sex. NS = correlation not significant at $P=.05$. 
TABLE 7. Correlations between CDI and three measures of body-size dimorphism in platyrrhine species: a) dimorphism in female $M^{1}$ area (ratio of male molar area to female molar area, 2) dimorphism in head and body length (ratio of male head and body length to female head and body length), and 3) dimorphism in body weight (ratio of male body weight to

\begin{tabular}{|c|c|c|c|c|}
\hline & $\mathrm{R}$ & DF & F-test & $\mathbf{P}$ \\
\hline \multicolumn{5}{|l|}{ CDI vs. $\mathrm{M}^{1}$ area dimorphism } \\
\hline 1. All platyrrhines & 0.72 & 25 & 25.17 & .0001 \\
\hline 2. Monogamous/polyandrous & 0.83 & 9 & 17.18 & .003 \\
\hline $\begin{array}{l}\text { 3. Multimale/multifemale low } \\
\text { competition or fission/ } \\
\text { fusion }\end{array}$ & 0.33 & 3 & 0.25 & NS \\
\hline $\begin{array}{l}\text { 4. Multimale/multifemale } \\
\text { breeding season } \\
\text { competition }\end{array}$ & 0.96 & 3 & 26.01 & .04 \\
\hline $\begin{array}{l}\text { 5. Single male or multimale/ } \\
\text { multifemale dominance } \\
\text { rank competition }\end{array}$ & 0.72 & 6 & 5.44 & NS \\
\hline \multicolumn{5}{|l|}{$\begin{array}{l}\text { CDI vs head and body length } \\
\text { dimorphism }\end{array}$} \\
\hline 1. All platyrrhines & 0.77 & 21 & 28.21 & .0001 \\
\hline 2. Monogamous/polyandrous & 0.74 & 8 & 8.44 & .023 \\
\hline $\begin{array}{l}\text { 3. Multimale/multifemale low } \\
\text { competition or fission/ } \\
\text { fusion }\end{array}$ & 0.78 & 2 & 1.56 & NS \\
\hline $\begin{array}{l}\text { 4. Multimale/multifemale } \\
\text { breeding season } \\
\text { competition }\end{array}$ & 0.06 & 3 & 0.008 & NS \\
\hline $\begin{array}{l}\text { 5. Single male or multimale/ } \\
\text { multifemale dominance } \\
\text { rank competition }\end{array}$ & 0.62 & 4 & 1.91 & NS \\
\hline \multicolumn{5}{|l|}{$\begin{array}{l}\text { CDI vs body weight } \\
\text { dimorphism }\end{array}$} \\
\hline 1. All platyrrhines & 0.62 & 15. & 8.83 & .01 \\
\hline 2. Monogamous/polyandrous & 0.17 & 5 & 0.12 & NS \\
\hline $\begin{array}{l}\text { 3. Multimale/multifemale low } \\
\text { competition or fission/ } \\
\text { fusion }\end{array}$ & $\begin{array}{l}\text { Insufficient } \\
\text { sample } \\
(n=2)\end{array}$ & & & \\
\hline $\begin{array}{l}\text { 4. Multimale/multifemale } \\
\text { breeding season } \\
\text { competition }\end{array}$ & 0.71 & 2 & 1.34 & NS \\
\hline $\begin{array}{l}\text { 5. Single male or multimale/ } \\
\text { multifemale dominance } \\
\text { rank competition }\end{array}$ & 0.74 & 3 & 2.48 & NS \\
\hline
\end{tabular}

\footnotetext{
${ }^{1} \mathrm{Just}$ one subspecies is selected to represent each species. For canine and molar dimorphism, samples are used only when species is represented by three or more specimens of each sex. NS $=$ correlation not significant at $\boldsymbol{P}=.05$
}

Depending on the model chosen, between 32 and $60 \%$ of the variance in canine dimorphism is explained by body size.

However, a very different pattern emerges when we attempt to subtract crudely the effects of breeding pattern. Within each level of breeding competition, no significant intertaxon correlations with body size are found. With the all-species data set (Table 6) there are 12 possible within-group comparisons; there is no significant correlation (i.e., $P<$ $=.05$ ) between CDI and body size in any case.

\section{Canine dimorphism and body-size dimorphism}

If we examine the association between canine dimorphism and body-size dimorphism there are indications that the two are not "produced" by the same selective factors. To assess the effects of body-size dimorphism on canine dimorphism we calculated the correlations between CDI and 1) molar area dimorphism, 2) head and body length dimorphism, and 3) body-weight dimorphism. Irrespective of which measure of body-size dimorphism is chosen, canine dimorphism increases as body-size dimorphism increases in platyrrhines. The product-moment correlation coefficients are $0.72,0.77$, and 0.62 , respectively (Table 7). When the sample is composed of just one species per genus, significant correlations are found only between head and body length dimorphism and CDI (Table 8). Thus, it appears that the selective factors influencing body-size dimorphism 
TABLE 8. Correlations between CDI and various measures of body size and body-size dimorphism (see Tables 6 and 7 for details) ${ }^{1}$

\begin{tabular}{lllll}
\hline CDI versus & $\mathrm{R}$ & $\mathrm{DF}$ & F-test & $P$ \\
\hline $\begin{array}{l}\text { Size measures } \\
\text { ln female molar area }\end{array}$ & 0.62 & 14 & 8.29 & .01 \\
$\begin{array}{l}\text { ln female head and } \\
\text { body length }\end{array}$ & 0.57 & 13 & 5.66 & .04 \\
$\begin{array}{l}\text { ln female body weight } \\
\begin{array}{l}\text { Dimorphism measures } \\
\text { Molar sexual dimorphism }\end{array}\end{array}$ & 0.64 & 14 & 9.16 & .01 \\
$\begin{array}{l}\text { Head and body length } \\
\text { sexual dimorphism }\end{array}$ & 0.24 & 14 & 0.81 & $\mathrm{NS}$ \\
$\begin{array}{l}\text { Body weight sexual } \\
\text { dimorphism }\end{array}$ & 0.60 & 13 & 6.71 & .02 \\
\hline Just one species is selected to represent each genus. & & 11 & 3.17 & $\mathrm{NS}$ \\
\hline
\end{tabular}

IJust one species is selected to represent each genus.

may not be the same ones controlling canine dimorphism, and this emerges most clearly if the effects of phyletic inertia are muted by using only one species per genus.

The same pattern generally emerges when we attempt to subtract crudely the effects of breeding pattern. With the all-species data set (Table 7) of 11 possible within-group comparisons, there is a significant correlation (i.e., $P<=.05$ ) between CDI and body size in just two cases involving monogamous/polyandrous species.

\section{Canine dimorphism and breeding competition}

When CDIs of platyrrhine species are segregated by the level of breeding competition, we observe a clear trend toward increased dimorphism with increased intermale competition. CDIs in our sample of platyrrhines range from a low of 0.98 in Aotus trivirgatus griseimembra to the high of 1.42 in Alouatta belzebul. Histograms of canine dimorphism are shown in Figure 1 for each level of intermale competition in our scheme. Here all species and subspecies are plotted and no statistical tests for the significance of differences among the groups are calculated.

Level 1 taxa, including species of Callithrix, Saguinus, Aotus, Callicebus, Leontopithecus, and Chiropotes, range from 0.98 (Aotus trivirgatus griseimembra) to 1.07 (Chiropotes satanas). The 13 lowest-ranking CDI species are all either monogamous or poly. androus.

Level 2 taxa (three Ateles species, Lagothrix flavicauda, Brachyteles arachnoides, and Pithecia pithecia) have CDIs between 1.08 and 1.18. Higher CDIs are found in level 3 taxa than in those of level 2 although there is a slight overlap between sampled taxa of the two levels. Four of five level 3 taxa (two Saimiri sciureus subspecies, Cebus capucinus, and Cacajao calvus) have CDIs between 1.15 and 1.20. Another level 3 taxon, Saimiri oerstedii, exhibits considerably more dimorphism (CDI $=1.25)$ than would be expected given its reportedly low level of intermale competition during the breeding season (Baldwin and Baldwin, 1981; Boinski, 1987). One possible explanation could be that intermale competition is extreme but occurs only at the time when the males reach sexual maturity and is followed by relative stability in adult social interactions. This explanation is supported by the fact that Saimiri oerstedii groups contain many more adult females than adult males (Baldwin and Baldwin, 1972).

Level 4 taxa, including Cebus apella and all species of Alouatta for which behavioral data are available, range from 1.22 (Cebus apella) to 1.40 (Alouatta fusca). The eight highest-ranking CDI species have social systems in which there is severe and/or protracted intermale competition for dominance. Thus, one might speculate that not only is there competition for access to mates (and perhaps female choice) during the mating season, but there is also competition among males at other times of the year for other limiting resources such as food.

The social structures of two taxa for which we have dimorphism data remain unstudied. Dimorphism in Lagothrix lagotricha falls at the lower end of level 4 species in terms of dimorphism-a sharp contrast to Lagothrix flavicauda, a level 2 species with low dimorphism. Alouatta belzebul has the highest CDI of any platyrrhine in this study, although perhaps not significantly higher than Alouatta fusca, a level 4 taxon. 

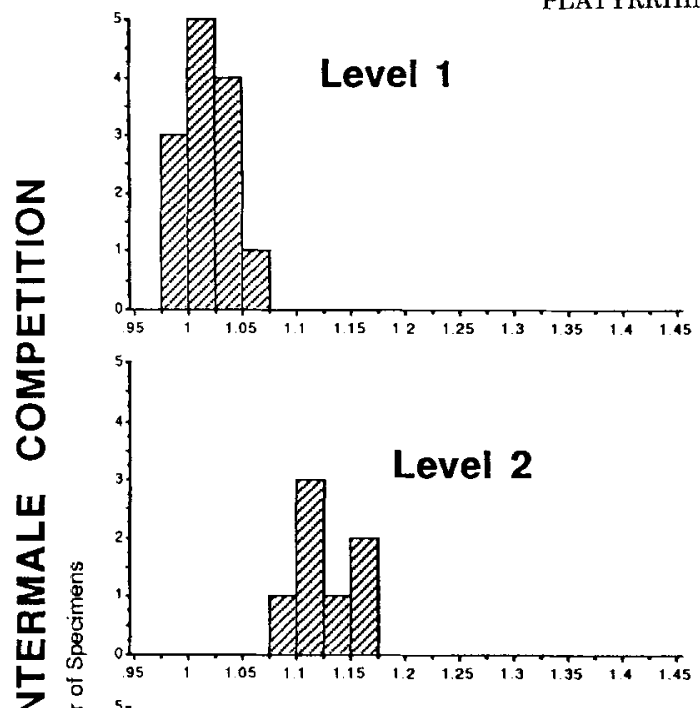

$z$
0
$\frac{z}{0}$
$\frac{1}{u}$
$\underline{0}$
$z$ 1

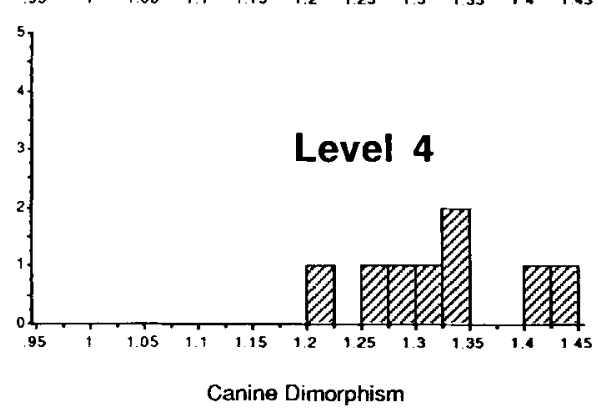

Fig. 1. Histograms of the canine dimorphism index (CDI) for species or subspecies of platyrrhines in the study sample. Separate histograms are provided for species falling within each of the four levels of breeding competition described in the text. Species are not plotted unless their behavior is known. A clear trend is noted for increased dimorphism with increased intermale competition. For individual CDIs, see Table 2

Joint assessment of the effects of size, size dimorphism, and breeding competition on canine dimorphism

As indicated above, analyzed separately, social structure appears to have the largest effect on canine dimorphism, and body-size dimorphism appears to be a significant but less important factor. Analysis of covariance (using the general linear model precedure in the Statistical Package for the Social Sciences) was used to assess how much of the variance in CDI is explained by each of these factors and the interactions among them when other factors are controlled for. In this analysis, social structure was treated as an ordered class variable with four states. Three separate analyses were made using each of the three size and size-dimorphism variables and their interaction terms. ${ }^{1}$ In model 1 (Table 9), in which $98.7 \%$ of the variance in canine dimorphism is explained, the independent variables were 1) competition level, 2) ln female weight, 3) weight dimorphism, 4) an interaction term for competition with weight and 5) an interaction term for competition with weight dimorphism. Of the independent variables examined, competition explains the most variance but body weight also explains a significant proportion of the variance $(P=.04)$. Taking the .05 level as the cutoff for significant variance, neither weight dimorphism nor either of the interaction terms has further significant explanatory power once the effects of the other independent variables are controlled. Models 2 and 3 (Table 9) are similar but employ head and body length and molar area as size and dimorphism variables. These analyses give similar results, explaining 97.9 and $95.9 \%$ of the variance, respectively. In both cases, competition is a very important explanatory variable. However, in model $2, \ln$ head and body length and head and body length dimorphism and the interaction terms all contribute significantly to explaining the variance in canine dimorphism, whereas in model 3 , once the effect of social structure is removed, none of the other factors is significant. Thus, several conclusions are possible: 1) Competition seems to be the most important predictor of canine dimorphism in platyrrhines in all three models. 2) Body size is also a significant but less important predictor in all three models. 3) Body size dimorphism is generally least important but is significant in the case of head and body length. 4) Interaction terms are only significant in the second model, which employs head and body length.

\footnotetext{
${ }^{1}$ One assumption of the analysis of covariance is the identity of slopes of regression equations between the dependent variable and each of the independent variables. In this case, this assumption appears to be violated. Therefore, we used a model with interaction terms for competition with size and competition with dimorphism.
} 
TABLE 9. Assessment of the contributions of three independent variables: 1) sexual competition (a four-level class variable), 2) body size, and 3) body-size dimorphism, to the dependent variable canine dimorphism (CDI) ${ }^{1}$

\begin{tabular}{|c|c|c|c|c|c|}
\hline Source & DF & $\begin{array}{l}\text { Sum of } \\
\text { squares }\end{array}$ & $\begin{array}{l}\text { Mean } \\
\text { square }\end{array}$ & F-value & $P$ \\
\hline \multicolumn{6}{|l|}{ Model $1^{2}$} \\
\hline $\begin{array}{l}\text { Model } \\
\text { Error }\end{array}$ & $\begin{array}{r}10 \\
4\end{array}$ & 0.2038 & 0.0204 & 32.36 & .0022 \\
\hline \multicolumn{6}{|l|}{ Corrected } \\
\hline total & 14 & 0.2063 & & & \\
\hline Competition & 3 & 0.0115 & & 9.14 & .0323 \\
\hline $\begin{array}{l}\text { Body-weight } \\
\text { dimorphism }\end{array}$ & 1 & 0.0029 & & 4.57 & $.0992(\mathrm{NS})$ \\
\hline \multicolumn{6}{|l|}{ Female } \\
\hline $\begin{array}{l}\text { Competition times body- } \\
\text { weight dimorphism }\end{array}$ & 3 & 0.0060 & & 4.75 & .0878 (NS) \\
\hline $\begin{array}{l}\text { Competition times } \\
\text { body weight }\end{array}$ & 2 & 0.0028 & & 2.21 & .2255 (NS) \\
\hline \multicolumn{6}{|l|}{ Model $2^{\mathrm{a}}$} \\
\hline $\begin{array}{l}\text { Model } \\
\text { Error }\end{array}$ & $\begin{array}{r}11 \\
8\end{array}$ & $\begin{array}{l}0.2912 \\
0.0062\end{array}$ & $\begin{array}{l}0.2647 \\
0.0008\end{array}$ & 34.26 & .0001 \\
\hline \multicolumn{6}{|l|}{ Corrected } \\
\hline \multicolumn{5}{|l|}{ H \& B length } & .0098 \\
\hline H \& B length & 1 & 0.0053 & & 6.85 & .0308 \\
\hline \multicolumn{6}{|l|}{$\begin{array}{l}\text { Competition times } \\
\text { H \& B length }\end{array}$} \\
\hline $\begin{array}{l}\text { dimorphism } \\
\text { Competition times }\end{array}$ & 3 & 0.0115 & & 4.96 & .0312 \\
\hline $\begin{array}{l}\text { Competition times } \\
\text { H \& B length }\end{array}$ & \multicolumn{5}{|c|}{ Competition times } \\
\hline \multicolumn{6}{|l|}{ Model $3^{4}$} \\
\hline Model & 11 & 0.4018 & 0.0365 & 38.03 & .0001 \\
\hline \multicolumn{6}{|l|}{ Corrected } \\
\hline total & 29 & 0.4191 & & & \\
\hline Competition & 3 & 0.0108 & & 3.75 & .0298 \\
\hline \multicolumn{6}{|l|}{ Molar } \\
\hline \multicolumn{6}{|l|}{ Female } \\
\hline molar size & 1 & 0.0006 & & 0.64 & .4355 (NS) \\
\hline \multicolumn{6}{|l|}{$\begin{array}{l}\text { Competition times } \\
\text { molar size }\end{array}$} \\
\hline $\begin{array}{l}\text { Competition times } \\
\text { molar size }\end{array}$ & & & & & \\
\hline molar size & 2 & 0.0035 & & 1.21 & $.3334(\mathrm{NS})$ \\
\hline
\end{tabular}

${ }^{1}$ Three separate analyses of covariance (type III) are summarized in which "body size" and dimorphism are based on molar area, head and body (H\&B) length, and body weight. Each model also takes into account the effects of interactions between CDI and body size and CDI and size dimorphism. In each model, CDI is the dependent variable.

${ }^{2}$ Independent variables: competition level, ln female body weight, body-weight dimorphism. Interaction terms: competition with ln female body weight, and competition with body-weight dimorphism. The model explains $98.8 \%$ of the variance in CDI.

${ }^{3}$ Independent variables: Competition level, female head and body length, head and body length dimorphism. Interaction terms: competition with ln female head and body length, and competition with head and body length dimorphism. The model explains $97.9 \%$ of the variance in CDI.

${ }^{4}$ Independent variables: Competition level, In female molar area, molar-area dimorphism. Interaction terms: competition with ln female molar area, and competition with molar area dimorphism. The model explains $95.9 \%$ of the variance in CDI.

\section{DISCUSSION}

Platyrrhine primates follow the general predictions of Rensch's rule of increased dimorphism with increased body size, and this is correlated at least in part with a tendency for larger species to exhibit more intermale breeding competition than smaller ones. However, this is not to say that selection for body-size increase by itself selects for a change in social structure, for within taxonomic groups with similar levels of competition no such correlation was found. Among medium and large-sized platyrrhines, there is almost as much variation in canine dimorphism and breeding systems as there is in platyrrhines as a whole. Saimiri, Aotus, and Callicebus are similar in size but range 
in the canine dimorphism index from 0.98 to 1.25 and in intermale competition from level 1 through level 3. Likewise, among large platyrrhines, Ateles, Brachyteles, Lagothrix, and Alouatta CDI ranges from 1.10 to 1.43 and breeding competition from level 2 to level 4.

These analyses suggest that sexual selection is the primary factor responsible for the observed pattern of canine dimorphism in platyrrhines. Thus, canine dimorphism increases in parallel with increased male-male competition for access to mates.

However, there is also some evidence that natural selection plays an important role in the evolution of increased canine dimorphism. The difference between intermale competition in level 3 and level 4 is essentially a temporal one; males of level 4 species maintain a dominance hierarchy over a protracted period of time whereas those in level 3 do so only during the mating season. Competition for access to females in the two groups may be equally intense and result in the same successful outcome for favored males. However, level 4 dominant males may also be increasing their fitness relative to low-ranking males by greater access to resources such as better feeding localities and sleeping sites or less exposure to predation. Note that we are not invoking feeding niche separation between the sexes-rather only a difference in relative competition among consexuals for access to these resources. Consideration of natural selection as a cause of sexual dimorphism has focused on the hypothesis that such selection will be reflected by differences in the diets of the sexes (e.g., Clutton-Brock et al., 1977; Clutton-Brock and Harvey, 1978). As far as we are aware, this analysis presents the first actual evidence among primates that natural selection via differential competition for limiting resources can effect the degree of sexual dimorphism expressed in a character. Thus we might predict that while competition for access to females should produce the same amount of dimorphism between level 3 and level 4 species, the additive effect of natural selection produces even greater dimorphism in level 4 species.

Other selective factors are thought to produce canine sexual dimorphism in mammals (see references above) but are unlikely to do so in platyrrhines. For example, all platyrrhine taxa except Aotus are diurnal. Therefore, an explanation for variation in dimorphism based on the tendency for diurnal mammals to have more complex social struc tures and increased selection for visually mediated secondary sexual characteristics could not account for different degrees of dimorphism within platyrrhines. Again, all platyrrhines are essentially arboreal so increased predation pressures of a terrestrial way of life, where there might be an increased role of male weapons (canines) in protecting the social unit, cannot be invoked to explain increased dimorphism in this group. Finally, feeding niche separation between the sexes is uncommon in platyrrhines and does not provide a general explanation for their canine dimorphism.

Nor does phylogenetic inertia play an important role in the differences observed in canine dimorphism. The considerable variation in dimorphism and breeding system that occurs within platyrrhine subfamilies (e.g., Pitheciinae and Atelinae) and even among species of a single genus (Lagothrix, Alouatta, Cebus, and Saimiri for example) attests the evolutionary lability of canine dimorphism. If phylogenetic inertia really were important in platyrrhine canine dimorphism, we would expect to find instances where canine dimorphism was unexpectedly higher or lower than would be predicted for the observed level of intermale competition. We find no evidence for such a situation.

This study of platyrrhine primates demonstrates a very strong link between canine dimorphism and breeding system. Level 1 taxa all have lower CDIs than taxa of any other level. Limited overlap occurs between level 2 and 3 breeding systems but level 3 species tend to be more dimorphic than those of level 2. Finally, level 4 taxa have higher CDIs than the other taxa. Natural selection via differential competition for resources, at least in level 4 taxa, also seems to play a role in the evolution of dimorphism. Other proposed explanations for sexual dimorphism (phyletic inertia, correlated response, and feeding niche separation) do not seem to be particularly important determinants of platyrrhine canine sexual dimorphism. As more is learned about the breeding systems of platyrrhines it will be desirable to further refine the system used here for measuring breeding competition. For example, the great variation among level 4 taxa, including Cebus and Alouatta, begs the question of whether there might be unappreciated variations in the breeding competition of species in this assemblage. Also, it should become possible to bring in other factors we have neglected be- 
cause the data are wanting: some of the variation within the levels of our scheme may result from intermale competition among juveniles and young adults as stable breeding systems are initially established.

These results are also notable in illustrating that there is generally a very low correlation between canine dimorphism and bodysize dimorphism. This suggests that different factors are controlling the evolution of dimorphism in body size and canine size, a phenomenon previously reported by Oxnard and colleagues (Oxnard 1983, 1987; Oxnard et al., 1985).

In this analysis we have dealt only with dimorphism - the relative size of male and female canines-not with the absolute or relative size of either male or female canines itself. For example, this analysis does not distinguish between one species in which both males and females have large canines for their body size and another in which both males and females have small canines. The absolute sizes of female and male canines will need to be studied before we can gain a more balanced understanding of the selective factors in canine evolution. Suppose, hypothetically, that the larger-canined males of a species are more successful in agonistic encounters with other males over access to mates. Suppose also that the females of our hypothetical species have their own dominance hierarchy established by agonistic encounters with other females in relation to some other resource like food. In this case, large canines might be selected in both males and females. One wonders whether a selective pattern of this nature might be operating in diurnal prosimians. Many of these animals have polygnous social systems and large, sharp canines in both sexes.

\section{ACKNOWLEDGMENTS}

We thank Matt Cartmill, Walter Leutenegger, Tab Rasmussen, Karen Strier, John G. Feagle, and Richard Thorington for their thoughtful comments. D.S. Burdick assisted with the analysis of covariance. This research was supported by NSF Grant BNS 8300646 to RFK.

\section{REFERENCES}

Aguire AC (1971) O Mono Brachyteles arachnoides Situaco a Teral da Especie no Brasil. Rio de Janeiro: Academia Brasileira de Ciencias.

Alonso C (1984) Observacoes de campo sobre o cuidado a prole e o daesenvolvimento dos filhotes de Callithrix jacchus jacchus. In MT de Mello (ed.): A Primatologia No Brasil. Rio de Janeiro, Brasil: Sociedade Brasileira de Primatologia, pp. 67-78.

Anderson CM (1986) Predation and primate evolution. Primates 27:15-39.

Ayres JMC (1981) Observacoes Sobre a Ecologia e o
Comportamento dos Cuxius (Chiropotes albinasus, Chiropotes satanas, Cebidae: Primates). Master Thesis. CNPq, INPA, FUA.

Ayres JMC (1986) Uakaris and Amazonian Flooded For. est. Doctoral Dissertation. Cambridge Unlversity.

Baldwin JD, and Baldwin, J (1972) The ecology and behavior of squirrel monkeys (Saimiri oerstedii) in a natural forest in western Panama. Folia Primatol. (Basel) 18:161-184.

Baldwin JD, and Baldwin JI (1981) The squirrel monkeys, genus Saimiri.In AF Coimbra-Filho and RA Mittermeier (eds.): Ecology and Behavior of Neotropical Primates, Vol. 1. Rio de Janeiro: Academia Brasileira de Ciencias, pp. 277-331.

Boinski, S. (1987) Mating patterns in squirrel monkeys (Saimiri oersted). Behav. Ecol. Sociobiol 21:13-21.

Brown $\mathrm{JL}$ (1975) The Evolution of Behavior. New York: Norton.

Buchanon DB, Mittermeier RA, and van Roosmalen MGM (1981) The saki monkeys, genus Pithecia. In AF Coimbra-Filho and RA Mittermeier (eds.): Ecology and Behavior of Neotropical Primates, Vol. 1. Rio de Janeiro: Academia Brasileira de Ciencias, pp. 391-419.

Cheverud J, Dow M, and Leutenegger W (1985a) The quantitative assessment of phylogenetic constraints in comparative analysis: Sexual dimorphism in body weight among primates. Evolution 39: 1335-1351.

Cheverud J, Leutenegger W, and Dow M (1985b) Phylogenetic autocorrelation and the correlates of sexual dimorphism in primates. Am J. Phys. Anthropol. 63: 145 .

Clarke MR (1983) Infant-killing and infant disappearance following male takeovers in a group of free-ranging howling monkeys (Alouatta palliata) in Costa Rica. Am. J. Primatol. 5:241-247.

Clutton-Brock TH, and Harvey PH (1978) Mammals, resources, and reproductive strategies. Nature 273:191195.

Clutton-Brock TH, Harvey PH, and Rudder B (1977) Sexual dimorphism, socionomic sex ratio and body weight in primates. Nature 269:797-800.

Coelho AM, Coelho LS, Bramblett CA, Bramblett SS and Quick LB (1976) Ecology, population characteristics, and sympatric association in primates: $A$ sociobioenergetic analysis of the energy budgets of howler and spider monkeys in Tikal, Guatemala. Yrbk. Phys. Anthropol. 20:96-135.

Crockett C, and Eisenberg JG (1987) In BB Smuts, DL Cheney, RM Seyfarth, RW Wrangham, and TT Struhs. aker (eds.): Primate Societies. Chicago: University of Chicago Press, pp. 54-68.

Darwin C (1871) The Descent of Man and Selection in Relation to Sex. London: J. Murray.

Da Silva EC, Jr. (1981) A preliminary survey of brown howler monkeys (Alouatta fusca) at the Cantareira Reserve (Sao Paulo, Brazil). Rev. Bras. Biol. 41:897909.

Dawson GA (1977) Composition and stability of social groups of the tamarin Saguinus oedipus geoffroyi, in Panama. In DG Kleiman (ed.): The Biology and Conservation of the Callitrichidae. Washington, DC: Smithsonian Inst. Press, pp. 23-27.

Defier TR (1983) Some population characteristics of $\mathrm{Cal}$ licebus torquatus lugens (Humboldt, 1812) (Primates: Cebidae) in eastern Colombia. Loziana 38:1-9.

Deitz LA (1985) Captive-born golden lion tamarins released into the wild: A report from the field. Primate Conservation 6:21-27.

Fedigan LM, and Baxter MJ (1984) Sex differences and social organization in free-ranging spider monkeys, Ateles geoffroyi. Primates 25:279-294.

Fontaine R (1981) The Uakaris, genus Cacajao. In A.F. Coimbra-Filho and R.A. Mittermeier (eds.): Ecology 
and Behavior of Neotropical Primates, Vol. 1. van Roosmelen, pp. 443-494.

Freese C, and Oppenheimer JR (1981) The capuchin monkey, genus Cebus. In AF Coimbra-Filho and RA Mittermeier (eds.): Ecology and Behavior of Neotropical Primates. Vol. 1. Rio de Janeiro: Academia Brasileira de Ciencias, pp. 331-390.

Gaulin SJC, and Sailor LD (1984) Sexual dimorphism in weight among the primates: The relative impact of allometry and sexual selection. Int. J. Primatol. 5:516536 .

Glander KG (1980) Reproduction and population growth in free-ranging mantled howling monkeys. Am. J. Phys. Anthropol. 53: 25-36.

Goldizen AW, and Terborgh J (1986) Cooperative polyandry and helping behavior in saddle-backed tamarins (Saguinus fuscicollis). In JG Else and PC Lee (eds.): Primate Ecology and Conservation. Cambridge: Cam bridge University Press, pp. 191-198.

Harcourt AH, Stewart KS, and Fossey D (1976) Male emigration and female transfer in wild mountain go rilla. Nature 263: 226-227.

Harvey PH, Kavanaugh M, and Clutton-Brock TH (1978) Sexual dimorphism in primate teeth. J. Zool. (London) 186:475-485.

Hernandez-Camacho J, and Cooper AW (1986) The non human primates of Colombia. In RW Thorington and PG Heltne (eds.): Neotropical Primates. Washington, DC: National Academy of Sciences, pp. 35-69.

Hershkovitz PH (1977) Living New Worid Monkeys, Vol 1. Chicago: University of Chicago Press.

Janson CH (1984) Female choice and mating system of the brown capuchin monkey Cebus apella (Primates: Cebidae). Z. Tier. 65:177-200.

Kay RF (1973) Mastication, Molar Tooth Structure, and Diet in Primates. PhD Dissertation, Yale University.

Kinzey WG, Rosenberger AL. Heisler PS, Prowse D, and Trilling J (1977) A preliminary field investigation of the yellow handed titi monkey, Callicebus torquatus torquatus, in northern Peru. Primates 18:159-181.

Klein L, and Klein D (1975) Social and ecological contrasts between four taxa of neotropical primates. In RH Tuttle (ed.): Socioecology and Psychology of Primates. The Hague: Mouton, pp. 59-85.

Leo Luna M (1980) First field study of the yellow-tailed woolly monkey. Oryx 151:366-389.

Leutenegger W, and Cheverud J (1982) Correlates of sexual dimorphism in primates: Ecological and size variables. Int. J. Primatol. 3:387-402

Leutenegger $W$, and Cheverud J (1985) Sexual dimorphism in primates: The effects of size. In WL Jungers (ed.) Size and Scaling in Primate Biology. New York: Plenum, pp. 32-50.

Leutenegger W, and Kelly JT (1977) Relationship of sexua] dimorphism in canine size and body size to social, behavioral and ecological correlates in anthropoid primates. Primates $18: 117-136$

Milton K (1978) The Foraging Strategy of Howling Monkeys. New York: Columbia Univ. Press.

Milton K (1985) Multimale mating and the absence of canine tooth dimorphism in woolly spider monkeys (Brachyteles arachnoides). Am. J. Phys. Anthropol. 68:519-523.

Napier PH (1976) Catalogue of Primates in the British Museum (Natural History). Part 1: Families Callitrichidae and Cebidae. London, British Museum (Natural History).

Neville MK (1972) Social relations within troops of red howler monkeys (Alouatta seniculus). Folia Primatol. (Basel) 18:47-77.

Neyman PF (1977) Some aspects of the biology of free- ranging cotton top tamarins (Saguinus o. oedipus) and conservation status of the species. In DG Kleiman (ed) The Biology and Conservation of the Callitrichidae Washington, DC: Smithsonian Inst. Press, pp. 39-71.

Oliveira 'MS, de Lima MG, Bonvincino $\mathrm{C}$, Fleagle $\mathrm{J}$ and Ayrer $A(1985)$ Preliminary notes on the ecology and behavior of the Guianan saki (Pithecia pithecia, Lin. naeus 1766; Cebidae, Primates). Acta Amazonica 15(1 2):249-263

Oxnard CE (1983) Sexual dimorphisms in the overall proportions of primates. Am. J. Primatol. 4:1-22.

Oxnard CE (1987) Fossils, Teeth and Sex. New Perspectives on Human Evolution. Seattle: University of Washington Press.

Oxnard CE, Liberman SS, and Gelvin BR (1985) Sexual dimorphism in dental dimensions of higher primates. Am. J. Primatol. 8:127-152.

Richard A (1974) Patterns of mating in Propithecus verreauxi verreauxi. In $\mathrm{RD}$ Martin, $\mathrm{GA}$ Doyle, and $\mathrm{AC}$ Walker (eds.) Prosimian Biology. London: Duckworth, pp. $49-74$.

Ridley M (1983) Explanation of Organic Diversity: The Comparative Method and Adaptations for Mating. Oxford: Clarendon Press.

Robinson JG, and Janson CH (1987) Capuchins, squirrel monkeys, and atelines: Socioecological convergence with old world primates. In BB Smuts, DL Cheney, RM Seyfarth, RW Wrangham, and TT Struhsaker (eds.): Primate Societies. Chicago: University of Chicago Press, pp. 69-82.

Rudran R (1979) The demography and social mobility of a red howler (Alouatta seniculus) population in Venezuela. In JF Eisenberg (ed.): Vertebrate Ecology in the Northern Neotropics. Washington: Smithsonian Inst. Press, pp. 107-126.

Smith RJ (1980) Interspecific scaling of maxillary canine size and shape in female primates: Relationships to social structure and diet. J. Hum. Evol. 10(2):165-173

Strier KB (1986) The Behavior and Ecology of the Woolly Spider Monkey, or Muriqui, Brachyteles arachnoides E. Geoffroy 1806. Ph.D. Dissertation, Harvard Univ.

Terborgh $J$, and Goldizen AW (1985) On the mating sys tem of the cooperatively breeding saddle-backed tamarin. Behav. Ecol. Sociobiol. 16:293-297.

Thorington RW, Ruiz JC, and Eisenberg JF (1984) A study of a black howling monkey (Alouatta caraya) population in northern Argentina. Am. J. Primatol 6:357-360

Trivers RI (1972) Parental investment and sexual selection. In B Campbell (ed.): Sexual Selection and the Descent of Man, 1871-1971. Chicago: Aldine, pp. 136179.

van Roosmalen MGM, Mittermeier RA, and Milton K (1981) The bearded sakis, genus Chiropotes. In AF Coimbra-Filho and RA Mittermeier (eds.): Ecology and Behavior of Neotropical Primates, Vol. 1. Rio de Janeiro: Acad. Brasileira de Ciencias, pp. 419-442.

Watts ES, Rico-Gray V and Chan C (1986) Monkeys of the Yucatan Peninsula, Mexico: Preliminary survey of their distribution and status. Primate Conservation 7:17-22.

White F (1986) Census and preliminary observations on the ecology of the black-faced black spider monkey (Ateles paniscus chamech) in Manu National Park, Peru. Am. J. Primatol. 11:125-132.

Wright PC (1978) Home range, activity pattern, and agonistic encounters of a group of night monkeys (Aotus trivirgatus) in Peru. Folia Primatol. (Basel) 29:43-55.

Wright PC (1986) Ecological correlates of monogamy in Aotus and Callicebus. In JG Else and PC Lee (eds.) Primate Ecology and Conservation. Cambridge: Cam bridge University Press, pp. 159-167. 